\title{
Peptide-Targeted Polymer Cancerostatics
}

\author{
E. BÖHMOVÁ ${ }^{1}$, R. POLA ${ }^{1}$ \\ ${ }^{1}$ Institute of Macromolecular Chemistry of the Czech Academy of Sciences, Prague, Czech \\ Republic
}

Received July 14, 2016

Accepted July 14, 2016

\section{Summary}

A tumor-targeting drug delivery system consists of a tumor recognition moiety and a directly linked cytotoxic agent or an agent attached to a water-soluble synthetic polymer carrier through a suitable linker. Conjugation of a drug with a polymer carrier can change its solubility, toxicity, biodistribution, blood clearance and therapeutic specificity. Increased therapeutic specificity of a polymer drug can be achieved by the attachment of a targeting moiety (e.g. a lectin, protein, antibody, or peptide) that specifically interacts with receptors on the target cells. A large number of tumor-specific peptides were described in recent years. After a short introduction, some important examples of peptide-targeted conjugates will be described and discussed.

\section{Key words}

HPMA copolymers • Tumor targeting • Peptides • Drug delivery system

\section{Corresponding author}

R. Pola, Department of Biomedicinal Polymers, Institute of Macromolecular Chemistry of the Czech Academy of Sciences, Heyrovského nám. 2, 16206 Prague 6, Czech Republic. E-mail: pola@imc.cas.cz

\section{Introduction}

Hydrophilic polymers are frequently used in various biologically oriented disciplines, particularly pharmacy and medicine. The application of both synthetic and natural polymers as carriers of biologically active substances in the treatment of many serious diseases has become a new sophisticated approach in modern medicine. Polymer carriers with a covalently bound drug are often called polymer therapeutics.

With the increasing number of tumor types, the attention of scientists is focused on the development of polymer therapeutics, particularly in the field of tumor therapy. In traditional chemotherapy, the free lowmolecular-weight cancerostatics are rapidly eliminated from the organism due to their relatively small molecular weight. At the higher doses required to achieve a sufficient therapeutic effect, they are also toxic to healthy organs and tissues, which is manifested by numerous unwanted side effects.

In contrast, the drug bound to the polymer carrier is transported in an inactive form in the bloodstream; it is maintained for a longer time in the circulation and after the polymer accumulates in the target tumor tissue, it may be released to achieve the desired cytotoxic effect. This feature can dramatically reduce the side effects of the drug, allowing the use of higher doses needed to achieve the maximal therapeutic effect.

However, there is still the problem of ensuring the preferential or specific transport of the drug to the tumor tissue, which can be achieved in two ways:

1. By utilizing tumor specificity, the high molecular weight polymeric cancerostatics are accumulated in solid tumors via the enhanced permeability and retention (EPR) effect (Maeda et al. 2006) (so-called passive targeting).

2. Using cell specificity, the drug effect is exclusively focused on the tumor cells due to cell receptor-specific targeting ligands that are bound to the polymer carrier (so-called active targeting).

There are many types of targeting ligands 
described in literature, such as antibodies, antibody fragments, carbohydrates, lectins, cytokines, vitamins, peptides, aptamers or hormones (Pearce et al. 2012).

Short synthetic oligopeptides (up to approximately 20 amino acids) are an important group of molecules with specific affinity to certain cell receptors. They consist of either sequences derived from the binding sites of important natural proteins (e.g. fibronectin or laminin) (Shadidi and Sioud 2003) or peptides discovered using combinatorial procedures, such as the so-called "phage display" method (Pande et al. 2010).

The peptides can be synthesized relatively easily. They are less immunogenic than large proteins, and they can be covalently linked to the polymer carriers using standard synthetic procedures. Some peptides can be used not only as targeting ligands but also as effective inhibitors of angiogenesis due to their interactions with the fast growing tumor endothelium (Mitra et al. 2006).

Damage to the endothelium leads to the formation of blood clots and clumps of platelets in blood vessels. Consequently, this blockade prevents the flow of oxygen and nutrients to the tumor and tumor regression (Leite de Oliveira et al. 2011).

\section{Development of the polymer drug carriers}

The attachment of a drug to both natural and synthetic polymer was first achieved more than 50 years ago (Jatzkewitz 1955). The advantage of natural polymers lies in their easy accessibility; generally they have a narrow molecular weight distribution and a biodegradable backbone. Difficulties may arise in the separation of conjugates prepared from such polymers, which may require several consecutive purification steps. Their use is often limited by their high immunogenicity, particularly after conjugation with the drug, low reproducibility and quality of the biopolymers obtained from various batches or sources.

In contrast, synthetic polymers may be tailormade precisely for the intended purpose; they may have various physico-chemical properties and may contain defined amount of various functional groups suitable for drug conjugation. Jatzkewitz (1955) performed one of the first studies to use a synthetic polymer as a drug carrier and used a dipeptide spacer to connect the drug (mescaline) to poly(vinylpyrrolidone). Ushak's group synthesized several water-soluble polymer-drug conjugates in the 1960s and 1970s (Panarin and Ushakov 1968).

In 1975, Helmut Ringsdorf designed his model of a pharmacologically active polymer. The model consisted of a biodegradable or biologically stable polymer that is also a carrier for at least three types of functional units. The polymer is not only the backbone of the system, its function is also to slow down the excretion of the drug from the body and simultaneously increase the probability of drug capture at the damaged site in the organism. The first unit, the so-called "solubilizer", increases the solubility of the system; the second unit enables attachment of a low-molecular-weight drug to the polymer chain. The drug is attached to the main chain via a spacer that is either stable under physiological conditions or it may be cleaved by hydrolysis or enzymatic process. The third unit, a transport system, is responsible for the transportation of the polymer into the target cells through the specific or nonspecific sorption of the polymer in the treated region in the organism.

Kopecek et al. (1991) further specified the structure of Ringsdorf's polymer drug model. He designed a water-soluble polymer carrier attached to lowmolecular-weight drugs via enzymatically cleavable oligopeptide spacers and targeting moieties that are responsible for the delivery of the whole system to the target cells. The peptide spacer is designed to be stable during the transport in the bloodstream; it is only cleaved after the system is internalized in the target cell.

Currently, low-molecular-weight drug-polymer conjugates (Chytil et al. 2015), polymer-protein conjugates (Pechar et al. 2011), polymer micelles with covalently bound drug (Chytil et al. 2012) and polyelectrolyte complexes for gene delivery (De Smedt et al. 2000) are all commonly called polymer therapeutics (SatchiFainaro et al. 2006).

All of these polymer systems consist of at least three parts: a water-soluble polymer, a spacer and a drug. The drug can be released from the polymer carrier via various mechanisms, depending on the type of the spacer between the drug and the polymer. The structure of the spacer is selected according to the desired site of action; the spacer for extracellular release must be designed differently from the spacer intended for intracellular activation.

The significant development of polymeric therapeutic agents occurred over the last 50 years. Numerous types of water-soluble polymer drug carriers, including homopolymers, copolymers of vinylpyrrolidone (Yoshioka et al. 2004), copolymers of acrylic and methacrylic acid (Chytil et al. 2010, Etrych et al. 2011, Nan et al. 2005), copolymers of styrene and maleic acid 
(Tsukigawa et al. 2015), poly(L-glutamic acid) (Li et al. 2013), poly(L-aspartic acid) (Zunino et al. 1982), poly(L-lysine) (Deng et al. 2007), polyethylene glycol (PEG) (Greenwald et al. 2000), polyoxazolines (Viegas et al. 2011), polysaccharides (dextrans, Ochi et al. 2005), cyclodextrins (Okamatsu et al. 2013) and proteins (albumin, Bolling et al. 2006), are described in the literature.

Currently, several anticancer polymer-drug conjugates are approved for clinical use, and some are in various stages of clinical trials (Duncan 2009, Canal et al. 2011). The copolymer styrene-maleic acid with neocarzinostatin (SMANCS) is currently the only clinically approved polymer-drug conjugate bearing a low-molecular-weight cytostatic for local administration. The second FDA-approved polymer-drug conjugate is the PEG-protein conjugate PEG-L-asparginase (Oncaspar), which is used to treat acute lymphoblastic leukemia and administered parenterally. Other polymer conjugates, including PEG-camptothecin (Garrett et al. 2013), poly(L-glutamic acid)-paclitaxel (Galic et al. 2011) and copolymers based on poly(N-2hydroxypropyl(methacrylamide) with camptothecin (Bissett et al. 2004) or paclitaxel (Terwogt et al. 2001) are being tested in clinical trials. Surprisingly, the number of the clinical applications is still very low considering the large number of research papers in the field.

In addition to the delivery of low-molecularweight drugs, synthetic polymers are also used for the modification of biologically active proteins. PEG-asparaginase is clinically approved for the treatment of acute lymphoblastic leukemia (Aldoss et al. 2016), and PEG-adenosine deaminase (Balasubramaniam et al. 2014) is indicated for certain human immunodeficiencies and for inborn adenosine deaminase deficiency.

\section{Passive versus active tumor targeting of polymer therapeutics}

Passive targeting of polymeric drug conjugates to solid tumors is based on the so-called enhanced permeability and retention (EPR) effect. This phenomenon is used to describe the enhanced nonspecific uptake of macromolecules from the bloodstream to the solid tumor and their accumulation in the tumor tissue due to the increased permeability of the tumor endothelium combined with the impaired or even absent lymphatic drainage in tumors. This phenomenon can be utilized in the design of the polymer cancerostatics, as the accumulation of the polymers in the tumor can be increased by increasing the molecular weight of the polymer (up to several hundred $\mathrm{kDa}$ ) (Maeda et al. 2006).

Passive targeting also reduces the toxic side effects of chemotherapy towards the healthy tissues. Unfortunately, it can only be utilized for targeting to well-vascularized tumors. Consequently, the efficiency of the EPR effect is reduced in smaller tumors ( $\mathrm{Lu}$ et al. 2002). These malignancies are also more difficult to detect and remove by surgery. Therefore, actively targeted polymer therapeutics become a more suitable strategy for their therapy. In leukemias, active targeting is the only option.

Active targeting is based on presumption that the target cells express specific membrane receptors (antigens) that can be recognized by suitable targeting ligands to enable the delivery of the actively targeted polymer conjugate to the cells. The discovery of the appropriate targeting ligands and their attachment to the polymer-drug conjugates is the cornerstone of active targeting.

In this review, we will focus on the selection and application of peptides as ligands for active targeting of polymer cancerostatics.

\section{Peptide ligands for active targeting}

Peptide ligands for active targeting can be distinguished according to the method by which they were selected:

1. Specific peptide sequences derived from ECM proteins, and

2. Peptides obtained by combinatorial methods (e.g. phage display libraries, synthetic peptide libraries).

Alternatively, they can be distinguished according to the type of cells to which they are directed:

1. Tumor cells, including metastases, and

2. Endothelial cells of the tumor endothelium.

\section{Specific peptide sequences derived from ECM proteins}

Peptide sequences can be derived from the binding sites of important natural proteins (e.g. fibronectin, fibrinogen, laminin, vitronectin, or thrombospondin) (Balaoing et al. 2015). More information is provided in the chapter entitled "Targeting the tumor endothelium".

Peptide sequences used for targeting can also be derived from the antigen binding region of antibodies. 


\section{Selection of the targeting peptides using combinatorial methods}

Substances with a specific affinity against an antigen or receptor can be identified using simple but very efficient combinatorial methods, such as synthetic peptide libraries or the phage display method. The latter was first described by Smith (1985). The method is based on the fact that combinations of all possible peptide sequences of certain length are prepared by recombinant technology and displayed on the surface of the filamentous bacteriophage fd. For example, the library of all possible tripeptides (consisting of 20 natural amino acids) contains 203 different sequences. Obviously, the longer the sequence, the more combinations must be taken into account. For longer sequences (with more than approximately 15 amino acids), the number of viral particles in the experiment can be lower than the number of possible peptide sequences. This strategy would result in an incomplete peptide library that might miss the peptides that bind to the desired antigen, as each phage carries only one peptide sequence. The phages are then multiplied in E. coli, resulting in a collection of bacteriophages with a single random peptide sequence of a given length attached to every phage particle known as a phage display library.

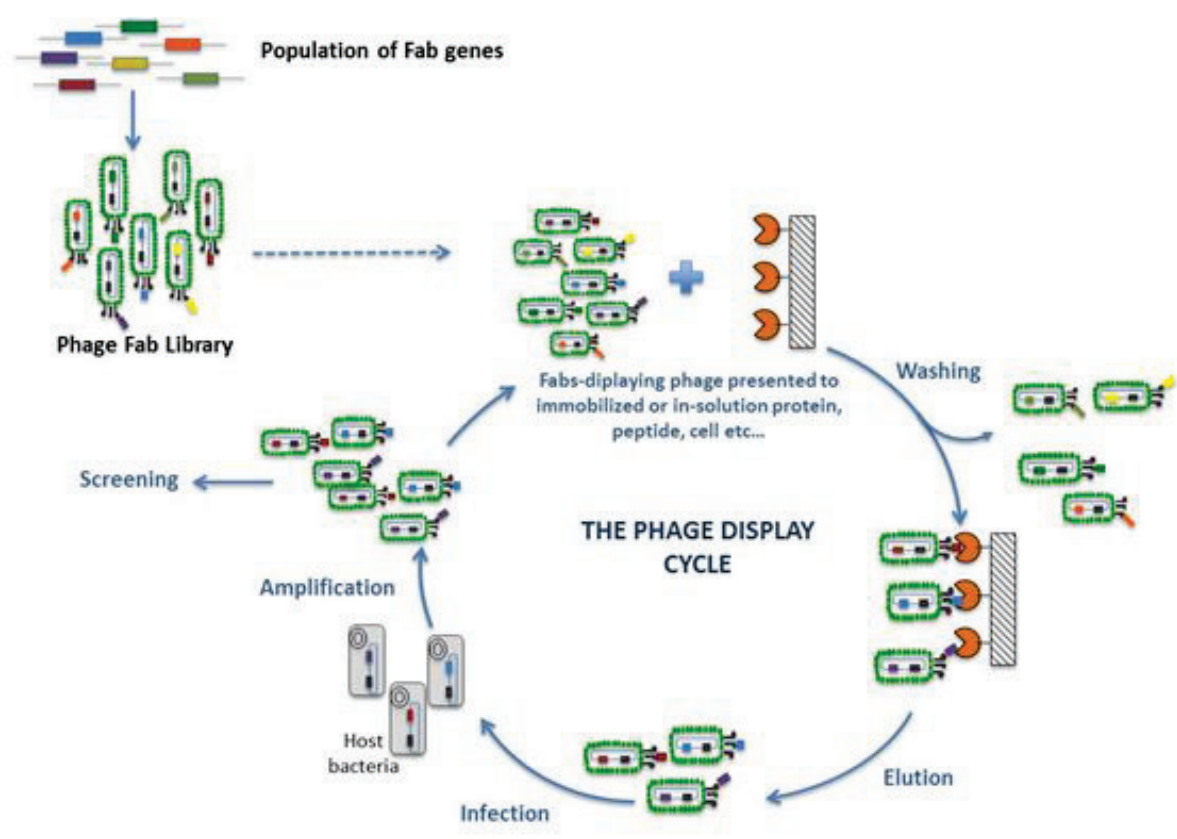

Fig. 1. The phage display method (http://fjb.pt/phage-display/).

Then, the phage library is applied to a column with the immobilized antigen of interest (Fig. 1). The phages bearing the peptides with certain affinity towards the antigen are captured on the column and the others are washed out. The antigen-bound phages are then selectively released from the column, multiplied in E. coli and purified on the column again. After 2-4 rounds of biopanning, the peptide sequence(s) with the highest affinity towards the antigen are selected and identified (Pande et al. 2010). Oligopeptides that specifically bind to the vasculature of various organs were identified after a direct i.v. injection of the phage display library into experimental animals in vivo. Ruoslahti and co-workers discovered that the RGD sequence specifically binds to $\alpha v \beta_{5}$ integrins (Pasqualini and Ruoslahti 1996).
The phage display method enabled the identification of numerous peptides targeting either to the tumor endothelium or directly to various types of tumor cells. The primary structure of some antibody binding sites was also verified using this method (Pande et al. 2010).

Many sequences that are already in various phases of clinical trials were identified using phage display (Table 1). Some of the peptides serve as targeting ligands of cytostatics (e.g. doxorubicin), (Pola et al. 2007) whereas others are used as tumor diagnostics in combination with radionuclides (Hruby et al. 2010), and may be eventually used to target viral (Parker et al. 2005) and non-viral (Huang et al. 2012) vectors for gene delivery. 
Table 1. Examples of peptides identified using phage display.

\begin{tabular}{cc}
\hline Peptide sequence & Cell target \\
\hline Antibody-derived & \\
$Y X X E D L R R R$ & \\
$X X P V D H G L$ & SUP-B8 human B-cell lymphoma, \\
FXDXRL, XIHYIF & Human myeloma, M-protein, \\
IELLQAR & E-Selectin \\
To tumor cells & \\
CTLVPHTRCGGGK & Prostate-specific antigen \\
TSPLNIHNGQKL & Flat head and neck cancer cells \\
LTVXPWX & Breast carcinoma cells \\
To tumor endothelium & \\
CDCRGDCFC $(R G D-4 C)$ & Integrins $\alpha_{\mathrm{V}} \beta_{3}$ and $\alpha_{\mathrm{V}} \beta_{5}$ \\
CGSLVRC, $C G L S D S C$, & Tumor vasculature \\
RRKRRR & VEGF \\
\hline
\end{tabular}

\section{Targeting to the tumor cells}

This type of targeting can be further divided to direct or indirect targeting (Minko et al. 2004). In the first case, the polymer conjugate is targeted directly to the tumor cells expressing the specific receptors that interact with the targeting ligands bound to the conjugate. First, the conjugate is bound to the receptor; then, it is internalized into the cell via the receptor-mediated endocytosis, which is significantly faster than fluid phase endocytosis. In other words, active tumor targeting is an attempt to selectively localize the biologically active substance in the tumor cells.

In contrast, indirect targeting usually refers to a specific anti-tumor response of the activated immune system against the tumor cells without the use of any chemotherapeutics. The targeting ligand is linked with a specific antigen that enables the malignant cells to be recognized by the immune system. This approach is sometimes called active specific immunotherapy (Khandare and Minko 2006).

\section{Targeting the tumor endothelium}

A new paradigm in cancer therapy was formulated by Folkman et al. (1971). It is based on the fact that the growing tumor tissue needs a continuous supply of nutrients that is provided by the newly formed tumor vasculature. If the formation of the new blood vessels - angiogenesis - is stopped, the tumor growth (including the formation of metastases) is discontinued and the starving tumor dies.
It was shown that a tumor larger than $1 \mathrm{~mm}$ in diameter or a tumor consisting of more than 108 cells needs its own vasculature to grow (Hanahan and Folkman 1996). This finding led to design and preparation of a new class of therapeutics targeted against the tumor endothelial cells forming the inner surface of the tumor blood vessels (Satchi-Fainaro et al. 2006).

The process of angiogenesis is accompanied by the increased expression of various growth factors and their corresponding cell receptors, as well as proteases and adhesion molecules (Carmeliet and Jain 2000), which all become new targets for antiangiogenic therapy. Tumor angiogenesis differs from the physiological angiogenesis with regard to the structure of the newly formed blood vessels, their permeability, blood flow and other properties.

Various cytostatic agents can be directed to vascular endothelial cells of the tumor (Pola et al. 2007). The advantage of targeting these cells is their direct accessibility from the bloodstream without need for drug extravasation. As a consequence of dying cells, blood clots and clumps of platelets within the tumor further obstruct the supply of nutrients for the tumor and subsequently inhibit tumor growth. In parallel, the formation of new blood vessels is stopped due to the inhibition of the cell receptors - integrins - responsible for the adhesion of the cells to the extracellular matrix. Another advantage of endothelial targeting is that the endothelial cells are genetically stable compared to cancer cells and thus they cannot become resistant to the cytotoxic agents. The high number of the angiogenic inhibitors that are currently being tested in clinical trials documents the importance of this strategy (Ellis et al. 2002).

This therapeutics can be divided into two groups. The first one includes drugs that target the already formed tumor blood vessels; the second group inhibits the formation of the tumor vasculature and simultaneously promotes the regression of existing vessels (Satchi-Fainaro et al. 2006). Endogenous angiogenesis inhibitors (Endostatin and Angiostatin) or vascular endothelial growth factor (VEGF) antagonists (Avastin) belong to the latter group. The cellular receptor inhibitors are often peptide sequences derived from proteins of the extracellular matrix (ECM). During angiogenesis, the endothelial stem cells are bound to ECM via specific receptors, integrins (Fig. 2). Integrins are responsible for cell-cell interactions and the interactions between cells and ECM proteins. The interaction between the integrins and ECM is mediated by specific peptide sequences that are derived from the ECM proteins. 


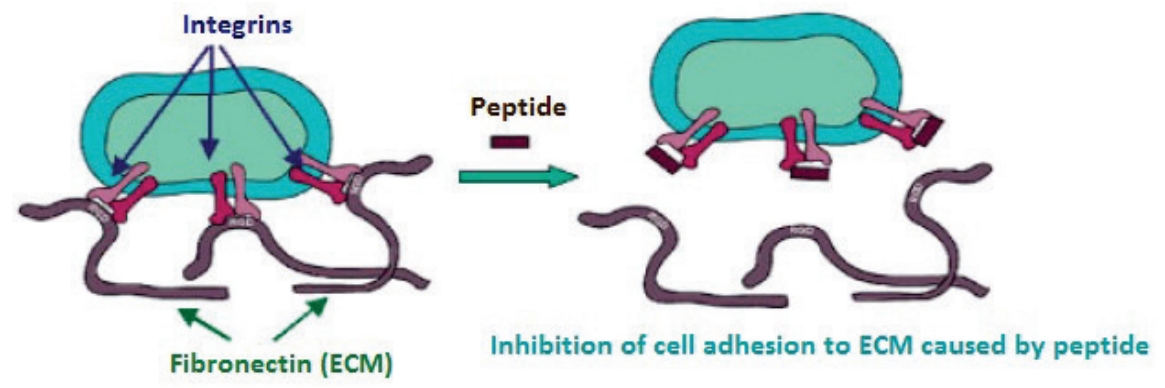

Fig. 2. The schematic of angiogenesis inhibition caused by binding of the peptide to cell surface integrins.
It was shown that $\alpha v \beta_{5}$ and $\alpha v \beta_{3}$ integrins significantly contribute to the formation of the tumor vasculature (Hynes 2002). These integrins are expressed on proliferating endothelial cells; they are mostly expressed during angiogenesis, whereas the non-dividing cells express almost no $\alpha \mathrm{v}$ integrins. Their inhibition blocks angiogenesis, which leads to tumor regression. The $\alpha v \beta_{3}$ antagonists are being tested as potential antitumor drugs in various stages of clinical trials. Tumor-related angiogenesis can be stopped by blocking this integrin with a lowmolecular-weight antagonist (Nisato et al. 2003).

Some therapeutics combines the effects of both groups, i.e. inhibition of angiogenesis and vascular therapy, to destroy the new tumor blood vessels. Combre- tastatins change the shape of the tumor endothelial cells, which results in thrombosis of the tumor blood vessels and tumor cell destruction (Zhang et al. 2011).

The pros and cons of vascular endothelial cell targeting versus tumor cell targeting are summarized in Table 2. Vascular targeting has several advantages. The endothelial cells are directly accessible from the bloodstream, in contrast to the tumor cells. Every endothelial cell is responsible for nurturing almost 100 tumor cells. Therefore, it is more efficient to kill the endothelial cells than the tumor cells. Moreover, the tumor cells are genetically unstable; their membrane receptors change over time (Alessi et al. 2004).

Table 2. Comparison of the two types of tumor targeting.

Endothelial cells (EC)

Genetic information

Action

Accessibility

Targets

Side effects

Duration of therapy

Regression

Result of therapy
Stable

1 EC nurtures 50-100 TC Cytotoxic

Directly from bloodstream

Specific receptors

Rare or none

Long

Slow

Stabilized disease

Avascular stage

Tumor regression

\section{Tumor cells (TC)}

\section{Unstable}

Development of resistance

$$
\text { All TC }
$$

Cytotoxic

Extravasation necessary

Few tumor cell-specific antigens

Rapidly dividing cells

$$
\begin{gathered}
\text { Yes } \\
\text { Short } \\
\text { Fast }
\end{gathered}
$$

Elimination of the tumor cells
The combination of the two types of the active targeting described above seems to be a more efficient therapeutic approach than targeting of both cell types separately.

\section{Peptide-based targeting ligands}

In recent years, many potential targeting ligands of various structures that were expected to successfully and reliably deliver therapeutics to tumor cells were designed, synthesized and evaluated, including unsaturated higher fatty acids (Lau and Archer 2010), small organic molecules (Satchi-Fainaro et al. 2004), polymers and other substances. Antibodies, antibody fragments and peptides derived from antibody binding sites exhibited very good tumor-targeting specificity 
(Zangemeister-Wittke 2005, Chytil et al. 2010).

The spatial accessibility of the targeting ligand and the corresponding cell receptor plays an important role in their interaction. This accessibility can be substantially affected by the length and structure of the spacer between the targeting unit and the polymer carrier. In this review, we will mostly focus on peptide-based targeting ligands.

In recent years, many peptides with potential therapeutic activity were discovered. The disadvantages of using natural peptides for direct therapeutic applications are their short half-life in the blood circulation, fast proteolytic degradation in vivo (Khandare and Minko 2006) and capture in kidneys (Adessi and Soto 2002). To increase their resistance to proteolysis, the peptides intended for therapeutic applications are usually chemically modified. The most common methods are incorporation of D-amino acids, cyclization or modification of the peptide termini.

Some peptides were also reported as carriers of cytostatics (Brokx et al. 2002) or as constituents of polymer drug carriers (Van Domeselaar et al. 2003). Other peptides exhibited good targeting either to various malignant cells or to tumor endothelial cells. Short peptides (up to 20 amino acids) can be prepared by solid phase synthesis, which is relatively easy and inexpensive. Recombinant DNA technology is more convenient for the preparation of longer sequences.

Peptides are relatively stable compounds; they can be relatively easily chemically modified. They can be covalently attached to a polymer carrier using standard chemical methods. The conjugation of the peptides to polymers improves their stability in the organism. Due to the selective binding of peptides to cell receptors, the peptides are ideal targeting ligands for various therapeutics (e.g. cancerostatics, oligonucleotides, toxins or radionuclides). In contrast to polymer-antibody conjugates, polymer-peptide conjugates are almost invisible to the immune system. Consequently, they exhibit minimal side effects (Shadidi and Sioud 2003) and they better penetrate the tumor tissue and the cell membranes. The peptides derived from antibody binding sites maintain their receptor binding affinity and specificity. Moreover, the corresponding polymer-peptide conjugates usually possess better defined structures.

The intracellular fate of the conjugate is influenced by numerous factors, including the type of the polymer carrier, the drug, the targeting ligand, the type of the cells being tested and the current phase of the cell cycle.

\section{Examples of peptide-targeted polymer cancerostatics}

There are still only a few papers in literature that describe oligopeptides as targeting moieties that are covalently bound to polymer carriers of biologically active molecules.

Polymer conjugates based on HPMA copolymers bearing RGD4C peptides labeled with radionuclides ${ }^{99} \mathrm{Tc}$ and ${ }^{90} \mathrm{Yb}$ were described, characterized and their biodistribution in mice was reported (Mitra et al. 2006). The corresponding conjugate with the RGE4C peptide was prepared and used as a negative control. The polymer conjugate with RGD4C inhibited cell adhesion in vitro by blocking of the $\alpha \mathrm{v} \beta_{3}$ integrin; the control polymer exhibited no activity. Similarly, the in vivo accumulation of the RGD4Ctargeted polymer in the tumor after $24 \mathrm{~h}$ was 1,000 times higher than the negative control. The targeted polymer was still detected in the tumor at $72 \mathrm{~h}$ after injection.

Another paper reported on the targeting of polymer conjugates with either RGD4C or c(RGDfK) containing ${ }^{111}$ In as a radioactive label (Mitra et al. 2006). Both types of polymer conjugates similarly bound to $\alpha v \beta_{3}$ integrin, thus blocking cell adhesion. Both polymers were detected in the tumor, even $192 \mathrm{~h}$ after injection in the mice.

The nonapeptide CPLHQRPMC, which has high affinity for PC3MM2 human prostate tumor cells, was identified using the phage display method. The polymer conjugate bearing doxorubicin was targeted using this peptide. The targeted conjugate exhibited significantly higher antiproliferative activity against PC3MM2 cells in vitro (Pola et al. 2007) compared with the non-targeted conjugate.

In addition, some polymer conjugates targeted with cyclic and linear RGD tripeptides were prepared and tested. The conjugate with cyclic RGD showed higher efficiency of targeting to endothelial cells compared with the conjugates with the linear form of RGD (Pola et al. 2009).

The targeting of RGD to $\alpha v \beta_{3}$ integrin and the CNGRC peptide to the membrane-bound enzyme aminopeptidase $\mathrm{N}$ was compared to passive targeting using the EPR effect in Kunjachan's study (Kunjachan et al. 2014). There was no significant difference between the actively targeted conjugates. They were both visible in the tumor endothelium soon after i.v. administration; however, their long term accumulation was reduced 
compared with the passively targeted conjugate.

The peptide sequence

GE-7

(NPVVGYIGERPQYRDL) derived from the EGF receptor was attached to a fluorescently labeled polymer carrier (Studenovsky et al. 2012). The measurements of binding activity showed that the polymer conjugate binds more efficiently to EGF receptor-rich cells (FaDu and MCF-7 cells) than to cells with low EGF receptor expression (SW620 and B16F10 cells).

Reactive HPMA-based copolymers targeted to tumor endothelium with YESIKVAVS (Stevenson et al. 2007) or SIGYPLP (Parker et al. 2005) peptides were successfully used for the surface modification of both viral and synthetic vectors for gene delivery.

Another publication showed that an HPMA copolymer containing the cancerostatic drug doxorubicin that was attached via the enzymatically cleavable tetrapeptide spacer GFLG and peptide sequence WHYPWFQNWAMA (Nan et al. 2005) selected by phage display method was used as a targeting ligand to selectively bind to squamous head and neck cancer cells. Internalization of the targeted polymer conjugate into the tumor cells followed by lysosomal uptake of the polymer and doxorubicin release was confirmed by confocal microscopy.

Another publication showed that a polymer conjugate used for gene delivery was composed of poly(ethyleneimine) as a carrier and the peptide DMPGTVLP as a targeting moiety linked via disulfide bridges. The peptide sequence was identified by the phage display method. This conjugate was used for gene delivery to breast adenocarcinoma cells (MCF-7). Hepatocellular carcinoma cells (HepG2) were used as a negative control. The transfection efficacy was approximately 2.6to 4-fold higher for the DMPGTVLP-poly(ethyleneimine) conjugate compared with the negative control (Mokhtarzadeh et al. 2015).

Zhong et al. (2015) prepared a polymer conjugate consisting of an HPMA copolymer carrier, the H1 peptide as a model drug and the R8 nuclear localization sequence (NLS) peptide as a targeting moiety. It consists of eight arginines and PKKKRKV.
A bi-forked structure consisting of the R8 NLS and the $\mathrm{H} 1$ peptide is attached to the polymer carrier via an enzymatically degradable GFLG spacer. The R8 NLS peptide refers to a cell penetrating peptide and a nuclear localization moiety. The model drug $\mathrm{H} 1$ peptide is derived from c-Myc; inhibition of c-Myc signaling pathway is one of the possible strategies of antitumor therapy. This conjugate exhibits prolonged blood circulation and a tumor homing ability (Zhong et al. 2015).

\section{Conclusions}

Targeted polymeric drugs represent wide range of possibilities for efficient tumor elimination. Currently, many antineoplastic macromolecular therapeutics are being developed that take advantage of either the EPR effect (passive targeting) or active targeting using various targeting ligands. These ligands target the polymer therapeutics either directly to the cancer cells or to the tumor endothelium. Synthetic oligopeptides are very important targeting moieties with the advantage of the relatively easy preparation of shorter amino acid sequences (up to ca $30 \mathrm{AA}$ ) using solid phase peptide synthesis. A large number of various tumor-targeting peptides have already been described in the literature; new peptides derived from natural proteins or identified by combinatorial methods (e.g. phage display) are being discovered every year. The diverse array of these peptides offers an excellent opportunity for improving the outcome of current neoplastic treatments.

\section{Conflict of Interest}

There is no conflict of interest.

\section{Acknowledgements}

The authors would like to thank Michal Pechar for support, useful advices and revision of the manuscript. The work was supported by the Ministry of Education, Youth and Sports of CR within the National Sustainability Program I (NPU I), Project POLYMAT LO1507.

\section{References}

ADESSI C, SOTO C: Converting a peptide into a drug: Strategies to improve stability and bioavailability. Curr Med Chem 9: 963-978, 2002.

ALDOSS I, DOUER D, BEHRENDT CE, CHAUDHARY P, MOHRBACHER A, VRONA J, PULLARKAT V: Toxicity profile of repeated doses of PEG-asparaginase incorporated into a pediatric-type regimen for adult acute lymphoblastic leukemia. Eur J Haematol 96: 375-380, 2016. 
ALESSI P, EBBINGHAUS C, NERI D: Molecular targeting of angiogenesis. Biochim Biophys Acta - Rev Cancer 1654: 39-49, 2004.

BALAOING LR, POST AD, LIN AY, TSENG H, MOAKE JL, GRANDE-ALLEN KJ: Laminin peptide-immobilized hydrogels modulate valve endothelial cell hemostatic regulation. PLoS One 10: $\mathrm{e} 0130749,2015$.

BALASUBRAMANIAM S, DULEY JA, CHRISTODOULOU J: Inborn errors of purine metabolism: clinical update and therapies. $J$ Inherit Metab Dis 37: 669-686, 2014.

BISSETT D, CASSIDY J, DE BONO JS, MUIRHEAD F, MAIN M, ROBSON L, FRAIER D, MAGNE ML, PELLIZZONI C, PORRO MG, SPINELLI R, SPEED W, TWELVES C: Phase I and pharmacokinetic (PK) study of MAG-CPT (PNU 166148): a polymeric derivative of camptothecin (CPT). Br J Cancer 91: 50-55, 2004.

BOLLING C, GRAEFE T, LUEBBING C, JANKEVICIUS F, UKTVERIS S, CESAS A, MEYER-MOLDENHAUER W-H, STARKMANN H, WEIGEL M, BURK K, HANAUSKE AR: Phase II study of MTX-HSA in combination with Cisplatin as first line treatment in patients with advanced or metastatic transitional cell carcinoma. Invest New Drugs 24: 521-527, 2006.

BROKX RD, BISLAND SK, GARIÉPY J: Designing peptide-based scaffolds as drug delivery vehicles. $J$ Control Release 78: 115-123, 2002.

CANAL F, SANCHIS J, VICENT MJ: Polymer--drug conjugates as nano-sized medicines. Curr Opin Biotechnol 22: 894-900, 2011.

CARMELIET P, JAIN RK: Angiogenesis in cancer and other diseases. Nature 407: 249-257, 2000.

CHYTIL P, ETRYCH T, KOSTKA L, ULBRICH K: Hydrolytically degradable polymer micelles for anticancer drug delivery to solid tumors. Macromol Chem Phys 213: 858-867, 2012.

CHYTIL P, ETRYCH T, KŘÍŽ J, SUBR V, ULBRICH K: N-(2-Hydroxypropyl)methacrylamide-based polymer conjugates with $\mathrm{pH}$-controlled activation of doxorubicin for cell-specific or passive tumour targeting. Synthesis by RAFT polymerisation and physicochemical characterisation. Eur J Pharm Sci 41: 473-482, 2010.

CHYTIL P, SIROVA M, KOZIOLOVA E, ULBRICH K, RIHOVA B, ETRYCH T: The comparison of in vivo properties of water-soluble HPMA-based polymer conjugates with doxorubicin prepared by controlled RAFT or free radical polymerization. Physiol Res 64 (Suppl 1): S41-S49, 2015.

DE SMEDT SC, DEMEESTER J, HENNINK WE: Cationic polymer based gene delivery systems. Pharm Res 17: 113$126,2000$.

DENG C, CHEN X, YU H, SUN J, LU T, JING X: A biodegradable triblock copolymer poly(ethylene glycol)-b-poly(llactide)-b-poly(l-lysine): Synthesis, self-assembly, and RGD peptide modification. Polymer (Guildf) 48: 139149, 2007.

DUNCAN R: Development of HPMA copolymer-anticancer conjugates: clinical experience and lessons learnt. $A d v$ Drug Deliv Rev 61: 1131-1148, 2009.

ELLIS LM, LIU WB, DO JUNG Y, REINMUTH N, STOELTZING O, TAKEDA A, AKAGI M, PARIKH AA, AHMAD S: Synopsis of angiogenesis inhibitors in oncology. Oncol York 16: 14-22, 2002.

ETRYCH T, STROHALM J, CHYTIL P, ČERNOCH P, STAROVOYTOVA L, PECHAR M, ULBRICH K: Biodegradable star HPMA polymer conjugates of doxorubicin for passive tumor targeting. Eur J Pharm Sci 42: 527-539, 2011.

FOLKMAN J, BACH M, ROWE JW, DAVIDOFF F, LAMBERT P, HIRSCH C, GOLDBERG A, HIATT HH, GLASS J, HENSHAW E: Tumor angiogenesis - therapeutic implications. $N$ Engl $J$ Med 285: 1182-1186, 1971.

GALIC VL, HERZOG TJ, WRIGHT JD, LEWIN SN: Paclitaxel poliglumex for ovarian cancer. Expert Opin Investig Drugs 20: 813-821, 2011.

GARRETT CR, BEKAII-SAAB TS, RYAN T, FISHER GA, CLIVE S, KAVAN P, SHACHAM-SHMUELI E, BUCHBINDER A, GOLDBERG RM: Randomized phase 2 study of pegylated SN-38 (EZN-2208) or irinotecan plus cetuximab in patients with advanced colorectal cancer. Cancer 119: 4223-4230, 2013.

GREENWALD RB, CONOVER CD, CHOE YH: Poly(ethylene glycol) conjugated drugs and prodrugs: A comprehensive review. Crit Rev Ther Drug Carrier Syst 17: 101-161, 2000. 
HANAHAN D, FOLKMAN J: Patterns and emerging mechanisms of the angiogenic switch during tumorigenesis. Cell 86: 353-364, 1996.

HRUBY M, KUCKA J, NOVAKOVA M, MACKOVA H, VETRIK M: New coupling strategy for radionuclide labeling of synthetic polymers. Appl Radiat Isot 68: 334-339, 2010.

HUANG P-I, LO W-L, CHERNG J-Y, CHIEN Y, CHIOU G-Y, CHIOU S-H: Non-viral delivery of RNA interference targeting cancer cells in cancer gene therapy. Curr Gene Ther 12: 275-284, 2012.

HYNES RO: Integrins: Bidirectional, allosteric signaling machines. Cell 110: 673-687, 2002.

JATZKEWITZ H: Peptamin (glycyl-L-leucyl-mescaline) bound to blood plasma expander (polyvinylpyrrolidone) as a new depot form of a biologically active primary amine (mescaline). ZNaturforsch 10b: 27-31, 1955.

KHANDARE JJ, MINKO T: Antibodies and peptides in cancer therapy. Crit Rev Ther Drug Carrier Syst 23: 401-435, 2006.

KOPECEK J, REJMANOVA P, STROHALM J, ULBRICH K, RIHOVA B, CHYTRY V, LLOYD JB, DUNCAN R: Synthetic polymeric drugs. Patent number 5037883, 1991.

KUNJACHAN S, POLA R, GREMSE F, THEEK B, EHLING J, MOECKEL D, HERMANNS-SACHWEH B, PECHAR M, ULBRICH K, HENNINK WE, STORM G, LEDERLE W, KIESLING F, LAMMERS T: Passive versus active tumor targeting using RGD- and NGR-modified polymeric nanomedicines. Nano Lett 14: 972981, 2014.

LAU DSY, ARCHER MC: The 10t,12c isomer of conjugated linoleic acid inhibits fatty acid synthase expression and enzyme activity in human breast, colon, and prostate cancer cells. Nutr Cancer 62: 116-121, 2010.

LEITE DE OLIVEIRA R, HAMM A, MAZZONE M: Growing tumor vessels: more than one way to skin a cat implications for angiogenesis targeted cancer therapies. Mol Aspects Med 32: 71-87, 2011.

LI M, SONG W, TANG Z, LV S, LIN L, SUN H, LI Q, YANG Y, HONG H, CHEN X: Nanoscaled poly(l-glutamic acid)/doxorubicin-amphiphile complex as $\mathrm{pH}$-responsive drug delivery system for effective treatment of nonsmall cell lung cancer. ACS Appl Mater Interfaces 5: 1781-1792, 2013.

LU ZR, SHIAH JG, SAKUMA S, KOPECKOVA P, KOPECEK J: Design of novel bioconjugates for targeted drug delivery. J Control Release 78: 165-173, 2002.

MAEDA H, GREISH K, FANG J: The EPR effect and polymeric drugs: A paradigm shift for cancer chemotherapy in the 21st century. Adv Polym Sci 193: 103-121, 2006.

MINKO T, DHARAP SS, PAKUNLU RI, WANG Y: Molecular targeting of drug delivery systems to cancer. Curr Drug Targets 5: 389-406, 2004.

MITRA A, NAN A, PAPADIMITRIOU JC, GHANDEHARI H, LINE BR: Polymer-peptide conjugates for angiogenesis targeted tumor radiotherapy. Nucl Med Biol 33: 43-52, 2006.

MOKHTARZADEH A, PARHIZ H, HASHEMI M, AYATOLLAHI S, ABNOUS K, RAMEZANI M: Targeted gene delivery to MCF-7 cells using peptide-conjugated polyethylenimine. AAPS PharmSciTech 16: 1025-1032, 2015.

NAN A, GHANDEHARI H, HEBERT C, SIAVASH H, NIKITAKIS N, REYNOLDS M, SAUK JJ: Water-soluble polymers for targeted drug delivery to human squamous carcinoma of head and neck. J Drug Target 13: 189$197,2005$.

NISATO RE, TILLE J, JONCZYK A, GOODMAN SL, PEPPER MS: alphav beta 3 and alphav B 5 integrin antagonists inhibit angiogenesis in vitro. Angiogenesis 6: 105-119, 2003.

OCHI Y, SHIOSE Y, KUGA H, KUMAZAWA E: A possible mechanism for the long-lasting antitumor effect of the macromolecular conjugate DE-310: mediation by cellular uptake and drug release of its active camptothecin analog DX-8951. Cancer Chemother Pharmacol 55: 323-332, 2005.

OKAMATSU A, MOTOYAMA K, ONODERA R, HIGASHI T, KOSHIGOE T, SHIMADA Y, HATTORI K, TAKEUCHI T, ARIMA H: Folate-appended $\beta$-cyclodextrin as a promising tumor targeting carrier for antitumor drugs in vitro and in vivo. Bioconjug Chem 24: 724-733, 2013.

PANARIN EF, USHAKOV SN: Synthesis of polymer salts and amides of penicillins. Pharm Chem Journal-Ussr 5: 260-267, 1968.

PANDE J, SZEWCZYK MM, GROVER AK: Phage display: Concept, innovations, applications and future. Biotechnol Adv 28: 849-858, 2010. 
PARKER AL, FISHER KD, OUPICKY D, READ ML, NICKLIN S A, BAKER AH, SEYMOUR LW: Enhanced gene transfer activity of peptide-targeted gene-delivery vectors. J Drug Target 13: 39-51, 2005.

PASQUALINI R, RUOSLAHTI E: Organ targeting in vivo using phage display peptide libraries. Nature 380: 364-366, 1996.

PEARCE TR, SHROFF K, KOKKOLI E: Peptide targeted lipid nanoparticles for anticancer drug delivery. Adv Mater 24: 3803-3822, 2012.

PECHAR M, POLA R, LAGA R, ULBRICH K, BEDNÁROVÁ L, MALOŇ P, SIEGLOVÁ I, KRÁL V, FÁBRY M, VANĚK O: Coiled coil peptides as universal linkers for the attachment of recombinant proteins to polymer therapeutics. Biomacromolecules 12: 3645-3655, 2011.

POLA R, PECHAR M, ULBRICH K, FRES AF: Polymer-doxorubicin conjugate with a synthetic peptide ligand targeted on prostate tumor. J Bioact Compat Polym 22: 602-620, 2007.

POLA R, STUDENOVSKÝ M, PECHAR M, ULBRICH K, HOVORKA O, VETVICKA D, RÍHOVÁ B: HPMA-copolymer conjugates targeted to tumor endothelium using synthetic oligopeptides. J Drug Target 17: 763-776, 2009.

RINGSDORF H: Structure and properties of pharmacologically active polymers. J Polym Sci Polym Symp 51: 135-153, 1975.

SATCHI-FAINARO R, DUNCAN R, BARNES CM: Polymer therapeutics for cancer: Current status and future challenges. Adv Polym Sci 193: 1-65, 2006.

SATCHI-FAINARO R, PUDER M, DAVIES JW, TRAN HT, SAMPSON DA, GREENE AK, CORFAS G, FOLKMAN J: Targeting angiogenesis with a conjugate of HPMA copolymer and TNP-470. Nat Med 10: 255261, 2004.

SHADIDI M, SIOUD M: Selective targeting of cancer cells using synthetic peptides. Drug Resist Updat 6: 363-371, 2003.

SMITH GP: Filamentous fusion phage - novel expression vectors that display cloned antigens on the virion surface. Science 228: 1315-1317, 1985.

STEVENSON M, HALE ABH, HALE SJ, GREEN NK, BLACK G, FISHER KD, ULBRICH K, FABRA A, SEYMOUR LW: Incorporation of a laminin-derived peptide (SIKVAV) on polymer-modified adenovirus permits tumor-specific targeting via alpha 6-integrins. Cancer Gene Ther 14: 335-345, 2007.

STUDENOVSKY M, POLA R, PECHAR M, ETRYCH T, ULBRICH K, KOVAR L, KABESOVA M, RIHOVA B: Polymer carriers for anticancer drugs targeted to EGF receptor. Macromol Biosci 12: 1714-1720, 2012.

TERWOGT JMM, HUININK WWT, SCHELLENS JHM, SCHOT M, MANDJES IAM, ZURLO MG, ROCCHETTI M, ROSING H, KOOPMAN FJ, BEIJNEN JH: Phase I clinical and pharmacokinetic study of PNU166945, a novel water-soluble polymer-conjugated prodrug of paclitaxel. Anticancer Drugs 12: 315-323, 2001.

TSUKIGAWA K, LIAO L, NAKAMURA H, FANG J, GREISH K, OTAGIRI M, MAEDA H: Synthesis and therapeutic effect of styrene-maleic acid copolymer-conjugated pirarubicin. Cancer Sci 106: 270-278, 2015.

VAN DOMESELAAR GH, KWON GS, ANDREW LC, WISHART DS: Application of solid phase peptide synthesis to engineering PEO-peptide block copolymers for drug delivery. Colloids Surfaces B Biointerfaces 30: 323-334, 2003.

VIEGAS TX, BENTLEY MD, HARRIS JM, FANG Z, YOON K, DIZMAN B, WEIMER R, MERO A, PASUT G, VERONESE FM: Polyoxazoline: chemistry, properties, and applications in drug delivery. Bioconjug Chem 22: 976-986, 2011.

YOSHIOKA Y, TSUTSUMI Y, MUKAI Y, SHIBATA H, OKAMOTO T, KANEDA Y, TSUNODA S, KAMADA H, KOIZUMI K, YAMAMOTO Y, MU Y, KODAIRA H, SATO-KAMADA K, NAKAGAWA S, MAYUMI T: Effective accumulation of poly(vinylpyrrolidone-co-vinyl laurate) into the spleen. $J$ Biomed Mater Res A 70: 219-223, 2004.

ZANGEMEISTER-WITTKE U: Antibodies for targeted cancer therapy - Technical aspects and clinical perspectives. Pathobiology 72: 279-286, 2005.

ZHANG M, GUO R, WANG Y, CAO X, SHEN M, SHI X: Multifunctional dendrimer/combretastatin A4 inclusion complexes enable in vitro targeted cancer therapy. Int J Nanomedicine 6: 2337-2349, 2011. 
ZHONG J, LI L, ZHU X, GUAN S, YANG Q, ZHOU Z, ZHANG Z, HUANG Y: A smart polymeric platform for multistage nucleus-targeted anticancer drug delivery. Biomaterials 65: 43-55, 2015.

ZUNINO F, GIULIANI F, SAVI G, DASDIA T, GAMBETTA R: Anti-tumor activity of daunorubicin linked to polyL-aspartic acid. Int J Cancer 30: 465-470, 1982. 